\title{
3. GOVERNANCE, LEGITIMACY AND THE RULE OF LAW IN THE SOUTH PACIFIC
}

By: Graham Hassall

\section{KEY TERMS AND PHRASES}

\section{Autocthonous}

Something that is autocthonous is formed, or originates, in the place that it is found. In this context the term is used when discussing constitutions that have been home-grown rather than imposed by outsiders or borrowed from western constitutional models.

\section{Governance}

Governance comprises the traditions, institutions, mechanisms and processes that determine how power is exercised. The concept of governance extends beyond formal government institutions, and includes a consideration of the role of citizens and non-governmental organisations (often referred to as civil society) and the insitutitions and processes by which civil society participates in governance within a society.

\section{Modern/modernity}

Modernism is a complex term used by a number of disciplines, including art history, literature studies and political studies. Within politics it is often used to represent a particular order that is based on a number of concepts that are in themselves complex. These include the concepts of nationhood and the rule of law. Also characteristic of modernity is the use of rationality or reason and a belief in certainty. The concept of 'western' industrialised nations may be thought to be an expression of modernity.

\section{Nationalism}

Nationalism refers to a commitment to nationhood and represents a complex web of ideas about the nature of the state and membership of it. Nations are imagined to be geographical and political communities of limited boundaries that are in themselves sovereign. They are often imagined to be 'natural' phenomena, arising because of 'natural' ethnic unity.

\section{The rule of law}

There are a number of definitions of, or jurisprudential statements on, the rule of law, with the jurist Albert V. Dicey's conception of the rule of law being possibly the most familiar. Key elements of the concept are limits to the exercise of power, equality before the law, predictable and stable laws and procedures and the separation of powers between various state authorities. 


\section{INTRODUCTION}

This chapter suggests that some of the difficulties now facing the states that came to independence in the South Pacific at different times in the second half of the twentieth century derive from the manner in which they were constituted. Although any state, at any time, may face political crises or economic setbacks, the seemingly endemic nature of corrupt practices by politicians and of societal unrest in such states as Papua New Guinea, Solomon Islands, Vanuatu and Fiji Islands suggests the presence of conflict at more fundamental levels. Concerns at the ability of new states to govern are not new. However, notions of quite recent origin that look at capacities for governance rather than just ideologies of political and legal legitimacy allow one to view the actual operation of constitutions in various Pacific island states in a new way. How well do the state systems that were established at independence provide governance to their citizens? If it is found that the institutions provided by the constitution create more disorder than order, deliver less justice than more, and result in deteriorating social and economic conditions rather than the reverse, then questions must be asked about regeneration of the constitutional foundations, as much as about their day-to-day operation.

In the South Pacific, where the essential aspects of the modern approach to law and constitution were adopted at independence, a survey of their subsequent operation suggests that capacities for governance remain limited, and that the legitimacy of introduced law remains contested. The multiple hindrances to the operation of introduced law include:

- how parliaments are functioning and how parliamentarians are acting (for instance legislative inaction, use of no confidence motions, use of electoral development funds, constituency representation);

- failures within electoral systems (for instance volatility of political parties, electoral violence);

- judicial scrutiny and activism (for instance controversy in the areas of finding the underlying law and protection of human rights, lack of judicial independence);

- the functioning of the executive, particularly cabinet ministers (for instance lack of accountability, difficulties in the provision of services such as health, education, transport and infrastructure);

- the functioning of a number of other executive agencies including the police and the defence forces; and

- the level of maturity of civil society.

How is it that new nations, defined so clearly in modern constitutions and laws, have not gained the moral authority promised at the moment of independence? This chapter suggests that one possible cause of so much contestation (and hence one crucial factor in establishing constitutional legitimacy) is the inadequate measures taken to 'ground' independence constitutions in the will of the people. Clearly, this 
is a question about values as much as about the efficacy of law. This chapter also proposes that the legitimacy of modern law and constitutions must be examined in the light of both normative considerations as well as more systemic approaches. Although modern states and law were introduced to the region from outside, with an expectation that the rule of law would be a sufficient support for development, modernisation, order and progress, insufficient attention was paid to the validity of the modern law system as a whole, or to the methods by which this system generated legitimacy in the eyes of those who are subject to it as citizens.

\section{Constitutions and Governance}

A constitutional system might be described as the sum of state and non-state actors that determine and affect the distribution and use of state power. The constitution channels the public power of the people. As described by Jan-Erik Lane, "...implicit in the concept of a constitution is the notion of restraints on State power". ${ }^{1}$ Modern constitutions seek to be effective and to provide the legal framework for the activities of all citizens (and others) in the state. When I say effective, I mean that they intend to influence the behaviour of every member of society by making laws about what is permissible to do and what is 'illegal'. The extent of effectiveness of a constitution can, perhaps, be determined by examining governance in a particular country.

Governance refers to the exercise of economic, political and administrative authority to manage a country's affairs at all levels. It comprises the mechanisms, processes and institutions through which citizens and groups articulate their interests, exercise their legal rights, meet their obligations and mediate their differences. ${ }^{2}$ The idea of governance is being promoted by states, intergovernmental agencies, and civil society. ${ }^{3}$ It is also being explored in relation to Pacific island countries' constitutions, and the proper operation of government. ${ }^{4}$ The concept of governance requires a state to find new ways of asserting its legitimacy and reinforcing its capacities to govern by consent. These new mechanisms include improving accountability, allowing for freedom of association and participation, providing free and fair legal frameworks in which individuals can act, allowing access to information, improving public sector efficiency, and boosting levels of cooperation between branches of government, the business sector and civil society.

\section{Modernity and the Rule of Law}

The constitutions that frame the exercise of state power in the new Pacific nations signify the legal norms of modernity. The term 'modern' has a particular meaning. It doesn't just mean contemporary, or in our times. Sociologist Anthony Giddens describes modernity as "...the institutions and modes of behaviour established first of all in post-feudal Europe, but which in the twentieth century increasingly have become world-historical in their impact". ${ }^{5}$ For present purposes, modernity will be used to signify a complex network of social norms, economic models, and political ideals sometimes summarised as 'the rule of law'. 
The rule of law is a doctrine concerning the proper construction of law and application of law developed in the United Kingdom and exported to other legal jurisdictions by the forces of history. ${ }^{7}$ Under the ideology of colonialism, the doctrine sought to impose reason on very different human societies. The ordering processes were known as pacification and development. ${ }^{8}$ Modern conceptions of the constitution' and 'the law' have come to the Pacific as part of this world-historical process. They seek to establish a paradigm of relations between members of society, and between the individual, the community, and the state.

The doctrine states that all people must be treated equally before the law, even though they may be acting for the monarch. The doctrine states, furthermore, that power will only be exercised in accordance with law. In other words, power will not be used arbitrarily. Additionally, the doctrine presumes the presence and desirability of a number of fundamental rights of citizens, including rights to freedom of the person, of speech, of movement and association. To speak of the rule of law, in other words, is to conjure a matrix of legal rules, values, institutions, and procedures, the absence of any one of which will lead to calls for the restoration of/ adherence to/ upholding of the rule of law.

The term rule of law is often used when describing approval or disapproval of the action or inaction of a government or a court. The rule of law is also sometimes referred to as constitutionalism, which has as its principal motivation the "restraining of state power", and "protection of the relatively powerless (individuals and minorities) from oppression by the powerful." The rule of law is thus a doctrine of legitimation for those who hold and exercise power in a constitutional state. Why is their tenure legitimate? Because they 'uphold the rule of law' (i.e., they restrain their use of power in accordance with the laws, which are made by them with the consent of 'the people').

\section{THE LEGITIMACY OF MODERN LAW}

The legitimacy of modern law derives from statements about the origin of law and about how the law is to be applied. The intention of modern law is to locate sovereignty in the people and treat every member of society equally before the law. The origin of the law, therefore, is said to be the will of the people, consenting to the law (through some sort of social contract) as it is a device to uphold their sovereignty and the rights that this entails. The second source of legitimacy, how the law is to be applied, is also a monitor of the legitimacy of the origins of the law, as law will only be effectively applied if it is popularly supported (in the absence of 'tyrannical' coercion).

In the initial decades following the attainment of independence by the small island groups in the South Pacific problems of colonial rule were supplanted by those of new nations. By the mid-1990s the stability of states was being challenged from within as much as from external factors. Ethnic conflict had destabilised Fiji, and separatist conflicts had greatly affected Papua New Guinea and Solomon Islands. Corrupt practices by politicians and public servants greatly occupied the media and 
state-agencies charged with upholding the law in these countries as well as such nearby states as Tonga, Vanuatu, Nauru, Cook Islands, French Polynesia and Samoa. The modern Pacific island state, like so many others beyond the Pacific region, gives the appearance of being populated by citizens who place more emphasis on selfinterest than public service. Within this atmosphere of corruption and instability the law is patently ineffective. This ineffectiveness is not rooted purely in resource issues that hinder the timely application of the law. Rather, a more fundamental disrespect for the law and its origins is indicated.

\section{The grounding of legitimacy in constitutional assent}

Although modern law locates sovereignty in the people and seeks to treat every member of society equally before the law, the constitutions of Pacific island states were rarely founded on consent by the people. On the contrary, most states in the region can truly be regarded as post-colonial in that their constitutional values and practices were either copied from colonial authorities or established in reaction to them. Colonial authorities, believing that subject peoples had little understanding of the issues at hand (and seeking to economise on time and expenses), generally established expert commissions or at best constituent assemblies comprising people's representatives, to complete constitutional exercises on their behalf. On this point Ghai has written:

In Papua New Guinea and Solomon Islands, vigorous attempts were made to consult with the people, through questionnaires and tours of the country by committees set up to recommend on the constitution for independence. However, the choices offered to the people, derived largely from the experience of the colonial powers, were complex, and their intricacies probably beyond the comprehension of most people. While this consultation lent an aura of legitimacy to the constitution, it did not significantly influence its contents. ${ }^{10}$

In the case of the British colonies, consultation within the colony was frequently limited to elite members of the various ethnic communities co-existing in the colony. The resulting constitutions were not the result of the free expression of the people but were rather the evidence of compromise between departing colonial masters and incoming national elites. In the cases of Solomon Islands, Gilbert Islands and Fiji, for instance, discussions on independence constitutions were held in London. Such constitutions, as a consequence, primarily allow access to the state by elites (usually recipients of western education or otherwise privileged under colonial rule), whether as representatives or as beneficiaries. The language of the law is not that of 'the people'.

There are other rationalisations than simple colonial paternalism for the lack of traditional concepts of governance being incorporated into Pacific island constitutions. By way of further rationalisation for such an approach Ghai has suggested:

Despite consultation with the people and the active involvement of their leaders, the constitutions cannot be said to be rooted in indigenous concepts of power, authority, and decision making, for a number of reasons. These lie in the difficulty 
of expanding these concepts, which are peculiar to an island or group, to the national scale; in the constitutional evolution over several decades of colonial rule along Western lines; in the emergence to eminence of an educated, Christianised and Westernised elite with a loyalty to and dependence on modern state institutions; and in the influence of successive bureaucrats and consultants. With them, notions of economic development and state management of resources had primacy, militating against experiments in participatory democracy. ${ }^{11}$

This modernist approach to nation-building through constitution-making had intended and unintended consequences. The resulting constitutions mirror those of the metropolitan powers, and almost all Pacific island states chose at independence a constitutional form familiar to them from the colonial era. Those associated with Britain, Australia and New Zealand operate parliamentary systems while those associated with France and the United States, presidential. They generally ignore the diversity of traditions within Pacific societies in their search for homogeneity and they are - consequently - elitist in nature, and valued more among the western educated than among the majority, whose constitutions (or systems of governance) continue to operate at village level. Perhaps most significantly, they don't fully come to terms with the orders of governance that pre-existed colonial rule and which continue to hold great significance (under the labels 'customary law' and 'traditional leaders') over the majority of the people.

At independence there was a vision of national parliaments replacing the foreign 'received' law with more relevant enactments and of national courts contributing law based more firmly on custom. Papua New Guinea's Constitution, for instance, expounds the doctrine of the 'underlying law', an indigenous common law that parliament and the judiciary were to create. This has not been the post-colonial experience, however, with programs of law reform faltering, and courts explaining that judgments based on custom were dependent on the quality of arguments placed before the courts that relied on such custom. John Gawi wrote in 1985 his view that the problem of Papua New Guinea's legal order was an institutional one. $\mathrm{He}$ suggested that the common law had become so entrenched in the country's legal system prior to independence, that it had become "an integral part of Papua New Guinean society":

Because of the nebulous nature of our pre-existing institutions (traditional institutions), common law with its institutional structure was able to force the traditional institutions to conform to the framework of the common law. What, in effect, happened was that our traditional institutions had been subsumed into the institutional framework of common law. Therefore, before the Constitution came, the only way we were able to describe our traditional institutions was to describe them by labels imposed on them by common law.... Our only hope was the Constitution, but the Constitution has failed. In fact the forces of common law are such that the Constitution is now being forced to conform to the institutions of common law. Every constitutional provision purportedly 
interpreted by the courts in Papua New Guinea is as good as a dead provision. As time goes by, and before we know it, the process of subsumption will be complete. ${ }^{12}$

Within the South Pacific region some progress has been made toward recovering an authentic constitution, or at least one which will not subjugate traditional orders of governance to western modes of order. When Solomon Islands conducted a constitutional review in the late 1980s, Prime Minister Alebua described the intention to his fellow parliamentarians:

Mr Speaker sir... the Constitutional Review Committee was deliberately set up without any outside legal advisor. Because what we are trying to work towards is a constitution of and for the Solomon Islands. Once we start putting in foreign influences sir, certainly it won't be a Solomon Islands Constitution. ${ }^{13}$

Another interesting instance of a people attempting to re-establish an authentic constitutional order occurred recently in Vanuatu. In February 1997 custom chiefs from four villages on the island of Ambae produced their own constitution establishing the responsibility of chiefs of certain villages in the area to protect and safeguard the general welfare of their people, protect and promote traditional values, resolve disputes and disagreements and assist the police and other authorities, including churches, schools and other social welfare institutions. Vanuatu's Constitution recognises custom chiefs but does not define their role in decisionmaking about non-traditional matters.

Such attempts have not, however, resulted in any substantive or formal changes to Pacific island constitutions. As the modern constitutions remain divorced from traditional order so too does the origin of the law in the will of the people remain, in large part, a fiction. This issue is at the heart of the failure of legitimacy of the rule of law in Pacific island states.

\section{Legitimacy, assent and nationalism}

A further challenge to constitutional legitimacy comes from the often unacknowledged link between social and political philosophies and constitutional design and practice. While liberal approaches to constitutionalism express concern at the outcomes of socialist and communist constitutionalism, the impact of philosophies premised on nation, race and religion must also be considered. Nationalism, for instance, when translated into nation-building laws governing language, education and mobility has often sought to suppress or even eradicate the cultural diversity that constituted the pre-colonial states and societies. These philosophies complicate the notion of assent. Whilst at one level there may be assent to an ideal unity, on another level the relationship between this ideal and the reality of cultural diversity creates a tension, and possibly a negation of any assumed assent. 


\section{Legitimacy and performance}

The second source of legitimacy, how the law is to be applied, also does not provide a basis for constitutional legitimacy. As already noted, success in establishing constitutional legitimacy has been hindered by problematic performance of constitutional duties in a number of South Pacific jurisdictions by various agencies.

\section{Instability of political parties}

Of particular note is the destabilising practice of strategic changes of political alliance by members of parliament (MPs). Democracies require (or imagine) communicative action, but through formalisation, legalisation and, increasingly, the constitutional recognition of party systems, democracies are increasingly beholden to strategic action. I say this because I see the following series of events being played out in a number of countries: peoples' representatives are elected to legislatures. Political parties (or interest groups) are established to marshal numbers in a bid to acquire more than $50 \%$ of the seats and therefore capture the executive (in some places, in a bid to capture the percentage of seats required to capture control over constitutional change). Loyalty to a party is premised on non-ideological factors and is increasingly liable to fluid movement of parliamentarians between parties. In an effort to promote executive stability, laws are being enacted to prevent party-hopping, or defection. Paradoxically, laws designed to promote political stability strike at the freedom of association that is at the heart of democratic societies. Paradoxically, too, the more that political practice is regulated by law, the more constrained the democratic process becomes.

The problem of stabilising political party systems is linked to two processes at the heart of constitutionalism: the performance of the legislative and executive branches of government. In a system in which the executive government is formed from within the legislature and in which political party affiliations are fluid, any executive government faces the challenge of maintaining the allegiance of its members. MPs may be enticed to cross the floor and, with the opposition groups, to form a new government with themselves in an improved situation. The necessity to form political party coalitions among parties - sometimes resulting in coalitions between a great number of parties - has significant impact on the capacity of parliaments and governments to carry out their duties.

An instance of the volatility of political parties occurred in Papua New Guinea in December 1999. A day after passage of the Budget for 2000, Prime Minister Morauta sacked the Deputy Prime Minister, John Pundari, and the Advance PNG Party, from the coalition government. ${ }^{14}$ In response to the new political environment a number of existing parties announced the formation of a new political group, the Peoples' National Alliance (PNA). ${ }^{15}$ There is other evidence in PNG that raises questions about the stability of the party system and its existence as anything more than a device that MPs use to marshal numbers within the Parliament. For more than two decades since Independence, for example, parties have not adhered to any system of legal registration other than as associations. ${ }^{16}$ 
Recent events in Cook Islands also demonstrate the problem. Although Cook Islands received assistance from several overseas agencies to improve electoral administration prior to general elections in July 1999, no amount of technical assistance could have prepared the country for the subsequent political turmoil. When incumbent Prime Minister, Sir Geoffrey Henry, appeared ready to form a coalition government with the leader of the New Alliance Party (NAP), Norman George, three members of Henry's Cook Islands Party defected after the ballot to help Joe Williams gain a majority in the 25-member Assembly. However, the Williams Government fell three and a half months later in a no-confidence vote that brought the Democratic Alliance Party (DAP) and the NAP coalition into government under Dr Terepai Moate.

In 1999 a three-member Commission of Political Review recommended a number of changes to Cook Islands political system to increase political stability and constitutional effectiveness. ${ }^{17}$ The Commission's report also recommended fostering of public discussion of future options of Cook Islands system of government and recommended a "more comprehensive national political review to be undertaken" after the term of the next Parliament.

To an increasing extent, in part because of the instability of party politics, electoral contests and even votes within parliaments are being decided in the courts rather than through counting of the ballots. In Vanuatu, for instance, Parliament became deadlocked in November 1997 over a no-confidence motion against the government of Prime Minister Serge Vohor. President Jean Marie Leye ordered dissolution of the Parliament, and following the dismissal of a challenge to this dissolution by the Vanuatu Court of Appeal in January 1998, general elections were held on March 6 at which no single party won enough seats in the 52 -member parliament to govern in its own right, ${ }^{18}$ and following which numerous allegations concerning malpractices were made. ${ }^{19}$

There are several options for the regulation of political parties, but some create dilemmas in terms of democratic theory. The view is sometimes put that a smaller number of stable parties is preferable to a larger number of more fluid parties. But legislating to limit the number of parties is commonly regarded as being a restriction on democratic choice. Similarly, preventing the defection of MPs from one party to another by laws that require defecting members to resign their seats and recontest with their new party at the next election is similarly a restrictive measure. MPs are, firstly, representatives of the people rather than of political parties, and so there must be concerns about laws that place control over the legislature and the executive in the hands of the parties.

Constitutional reform in Papua New Guinea has sought to limit the impact of electoral contests by reducing the nomination period for candidates and reducing the formal campaign period..$^{20}$ After a long process the Parliament has also created an organic law concerning the integrity of political parties and candidates as required by sections 129 and 130 of the Constitution. ${ }^{21}$ As a major cause of political instability since Independence has been the volatility of MP loyalty to political parties, the government is seeking to strengthen the party system and diminish the prevalence of 
'party-hopping'. To achieve this, the Organic Law provides for the dismissal from Parliament of an MP who defects to a political party other than the one for which he or she was elected to Parliament. ${ }^{22}$

Political parties have expressed concern, however, that the draft provisions are too harsh and penalise MPs who seek to change parties with valid reasons. The Pangu Pati, one of the oldest political groups in Papua New Guinea, has suggested that the Organic Law should also restrict the formation of new political parties "on the floor of Parliament", and restrict the influence of independent MPs. ${ }^{23}$ Melanesian Alliance leader, John Momis, who is one of the "Founding Fathers" of the Papua New Guinea Constitution, has also called for constitutional change, but has not defined the "radical measures" to the Westminster system he envisages. ${ }^{24}$

\section{The functioning of the executive}

The functioning of the executive is another area in which the inadequate performance of duties weakens the legitimacy of the constitution. In parliamentary systems executive power is exercised by or on advice from a cabinet, derived from the legislature. Since executive power is often regarded as the most powerful branch of government, it is often the most coveted by political interests. It is subject also to the most scrutiny by other public bodies, particularly the legislature, but also the courts, on application, and other offices such as that of the ombudsman and auditor-general.

In Pacific island states MPs tend to desire active roles in executive government. The traditional argument in favour of this involvement has been that MPs have been obliged to assist in the delivery of services in response to people's expectations of a 'big man' ${ }^{25}$ But it may be that the participation of MPs in the planning and delivery of services has unintended effects, such as drawing resources away from the line departments ordinarily responsible for such activities, or possibly leading to overlaps in the delivery of services. Furthermore, the involvement of MPs in service planning and delivery leaves them little time for other parliamentary duties, such as the development of legislation, committee service and scrutiny of government. A more sceptical view would be that MPs have simply sought to exercise control over budgets, specific programs and statutory bodies. In the long term, the role of the MP will require clarification, particularly as a more educated public begins to ask incisive questions concerning the ideal role of elected representatives.

In a number of Pacific island states there have been unprecedented incidents of public agitation against the corrupt and incompetent actions of executive governments. For instance, in Samoa in October 1998 five thousand people gathered to protest against the Alesana government. Principle concerns were the sacking of auditor-general Sua Rimoni Ah Chong in August, illegal sale of passports and the fact that the public accounts had not been audited for approximately eight years. ${ }^{26}$ 


\section{INSTABILITY AND CONSTITUTIONAL LEGITIMACY}

Civil violence is probably the most extreme expression of weaknesses in the constitution of countries and their law. Such violence is now becoming a familiar part of Pacific island politics, particularly in Melanesia, where expressions of violence have resulted in destabilised states. As the experience of Solomon Islands, Papua New Guinea and Fiji Islands indicate, instability is tied up with a lack of consistutional legitimacy.

Examining Solomon Islands first, this nation opted for a parliamentary democracy with the Queen as Head of State and her representative, the Governor General, elected by Parliament. There was to be a single chamber legislature and, recognising the hazards of party government in Solomon Islands, the Prime Minister was to be elected by and from the members of Parliament and could be removed only by a motion of no-confidence. But neither the Solomon Islands state, nor its constitution, nor the rule of law ideology has provided sufficient legal, administrative, or conceptual authority to prevent endemic corruption in public office or resurgent ethnic and political conflict.

Although long-standing separatist sentiments in Solomon Islands are well known, their eruption in the late 1990s has proven difficult to resolve. The escalation commenced with legal disputes between national and provincial politicians. In 1997 the High Court invalidated the Provincial Government Act 1996, which had sought to replace Provincial Premiers with elected provincial councils in an effort to decrease cost and improve the efficiency of government services. The Malaita and Guadalcanal Provincial Governments had threatened secession on passage of the Bill, and the successful challenge was made by the government of Guadalcanal. In 1999 the heads of the Solomon Islands' nine provinces recommended that the national Constitution and the Provincial Government Act 1996 be reviewed. Guadalcanal province commenced seeking compensation for the use of land, especially in and near Honiara, under use by the national government. Tensions on Guadalcanal between landowners and settlers from outer islands then became violent, and on June 161999 the government invoked a state of emergency. ${ }^{27}$ Although Commonwealth special envoy to Solomon Islands, former Prime Minister of Fiji Sitiveni Rabuka, negotiated a peace accord, violence continued and the factors underlying the conflict remained unaddressed. On June 52000 members of the Malaita Eagle Force, along with a faction of police officers, the Seagulls, detained then Prime Minister Ulufa'alu and demanded his resignnation. On 13 June, Ulufa'alu submitted his resignation and on 30 June, Manasseh Sogavare was elected Prime Minister and a new government was formed. On 15 October 2000 the Townsville Peace Agreement was signed, the 7th peace agreement since June of 1999. Although this agreement has not restored stability it has created a cease-fire situation. Elections were held on 5 December 2001, and it is widely acknowledged that the first responsibility of the new government will be the rebuilding of order, or reconstitution of the state, in such a way as to ensure lasting peace. ${ }^{28}$ 
The myth of the modern constitution being written by the people is particularly prevalent in Papua New Guinea. However, almost thirty years after independence there is still uncertainty concerning the extent to which the nation of Papua New Guinea is governed by the rule of law. Here, as in Solomon Islands, corruption and ethnic conflict have weakened the basis of the state and called into question its capacity to govern and to apply the rule of law.

A crisis of legitimacy has been felt most severely in Bougainville. Since Independence conflict over the status of this province has been in part a conflict over the question of devolution of power. It is a question at the heart of the Constitution and its resolution can only be found through constitutional dialogue. The Bougainville Reconciliation Government (BRG), frustrated at the national Parliament's inability to put the Bougainville conflict above political in-fighting, convened a Constitutional Convention on 24 December 1998, at which a BRG Constitution was adopted by acclamation, to provide for the establishment of a Bougainville Constituent Assembly (BCA) as an advisory body ahead of the election of a BRG. The BCA met on 15-16 January 1999 and adopted the BRG Basic Agreement and the BRG Constitution. The National Executive Council (NEC) subsequently endorsed the BRG Basic Agreement but did not consider the BRG Constitution. In May 1999 the people of Bougainville elected 69 members to the Bougainville Reconciliation Government. Joseph Kabui was elected President. After a long process of peace talks, the Bougainville Peace Agreement, signed at Arawa on 30 August 2001 "provides for arrangements for an autonomous Bougainville Government operating under a homegrown Bougainville Consistution..."29 This Bougainville-wide exercise, however, does not constitute a Papua New Guinea-wide constitutional reform exercise. ${ }^{30}$

Recent events in Fiji, where the Constitution has undergone the most significant processes of reform of any South Pacific state since independence, further illustrate the tenuous authority of the modern constitution and state. Negotiations with the British resulted in independence in 1970. Two military coups occurred in 1987, when Fijian interests perceived a threat to Fijian hegemony from Fiji-Indian interests. ${ }^{31}$ Despite the promulgation of a new constitution in 1990 which met with the satisfaction of those who instigated the coups, a constitutionally mandated constitutional review undertaken by the Reeves Commission in $1997^{32}$ failed to maintain this appeasement, and in 2000 the state was once again thrown into disarray when George Speight named the protection of Fijian interests as his paramount reason for storming the Parliament and attempting to overthrow the Mahendra Chaudhry government. Whilst the courts intervened in the situation and upheld the validity of the 1997 Constitution the ongoing disorder that was created by Speight's actions does little to create the impression of authoritative constitutional order in Fiji Islands.

\section{THE REGENERATION OF LEGITIMACY}

This instability is indicative of a need to reconsider the constitutions, and not just their day-to-day workings, in order to regenerate legitimacy and create lasting order. In a recent work, Between Facts and Norms, Habermas has sought the reasons for the 
large distance that sometimes appears between the ideal laws of a society and the actual practice of that society. He suggests, ultimately, that the 'most effective law' results from procedures that all who are affected by that law can participate in:

From the standpoint of legal theory, the modern legal order can draw its legitimacy only from the idea of self-determination: citizens should always be able to understand themselves as authors of the law to which they are subject as addressees. ${ }^{34}$

Habermas and others have developed a theory of discourse ethics based on a distinction between strategic and communicative action. In strategic action:

... actors are interested solely in the success, ie, the consequences of the outcomes of their actions, [and] they will try to reach their objectives by influencing their opponent's definition of the situation, and thus his decision or motives, through means by using weapons or goods, threats or enticements. ${ }^{35}$

Communicative action, on the other hand, is oriented toward reaching a common understanding rather than achieving personal success. ${ }^{36}$ What is required is a paradigm shift, not simply a tinkering with the system. This involves new understandings of relations between law and power. When applied to the challenge of renewing the legitimacy of the constitutions in Pacific island jurisdictions, one major challenge will be to increase understanding of this distinction between communicative and strategic action. Some may conclude that communicative action remains an ideal and that all discourse, including constitutional discourse, is strategic in purpose. Yet the challenge remains of finding some form of discourse concerning the structure and operation of the constitution that keeps its interests beyond the party-political, beyond the interests of any particular group in that society.

It should be noted that there are difficulties in maintaining clear distinctions between communicative and strategic action. These difficulties can be observed in the recent history of Papua New Guinea's Constitutional Review Committee (later the Constitutional Development Commission (CDC)). MP Philemon Embel, having been appointed Chair of the Commission in May 1999, was recalled to Cabinet in July and replaced by MP Bernard Mollok. Charged with overseeing the drafting of an Organic Law on the Integrity of Political Parties and Candidates (as required by ss 129 and 130 of the Constitution), Mollok called on the government to undertake a total review of the PNG Constitution, rather than the "piecemeal approaches" which had occurred in recent years. ${ }^{37}$ The Chairman identified existing electoral laws, and the behaviour that takes place during electoral periods, as indicative of the "foreign concepts" of governing that had created problems for the country. ${ }^{38}$ However, when the Chairman began publicly to berate the government for giving the CDC inadequate resources and insufficient time to complete its work, ${ }^{39}$ and eventually claimed that the government was not supporting the work of the $\mathrm{CDC},{ }^{40}$ he was removed from the position. ${ }^{41}$ 


\section{Mechanisms for amending constitutions}

The most common ways in which a constitution can be amended are through a vote in parliament or through other means which allow 'the people' to have control over any changes such as referenda or constitutional conventions. Another mechanism, in which the role of public involvement can vary widely, is the expert commission, such as the Reeves Commission that reported on the Fijian Constitution in $1996 .{ }^{42}$

Constitutional conventions tend to be held when large-scale change to a constitution is envisaged, rather than change to specific provisions only. The idea is to allow for full consultation on the issues, or communicative action. Such conventions have been held in Pacific island nations such as the Federated States of Micronesia and the Marshall Islands. The Commonwealth of the Northern Mariana Islands, a nation that has chosen to be in free association with the United States, established a constitutional convention in 1974 following a vote by the people which gained $75 \%$ approval. A second constitutional convention held in 1984 proposed 44 constitutional amendments, all of which were approved by the people.

At Kiribati's first constitutional convention (March 2-6 1998) some 200 delegates consulted on a report prepared for the convention by a Parliamentary Select Committee. The convention's proposals and recommendations included increasing the members of the Council of State from three to either four or five, although different views were put as to who the additional members should be. The proposed amendments will be put to public comment before debate in Parliament, where they require a two-thirds majority to pass.

A constitutional convention may sound expensive to hold, but where they succeed in bringing together the people's representatives to discuss the foundations of the state system, they help to establish the legitimacy of the constitution. By ensuring that the constitution truly expresses the wishes of the people as they evolve over time, such a form of structured public dialogue as a constitutional convention consolidates legitimacy through communicative action, and in doing so, contributes to the attainment of such other goals as democracy, justice and prosperity. States that do not respond effectively to the need to consolidate legitimacy risk serious internal conflicts and social instability.

\section{Legitimacy and related goals}

The first goal of any exercise aiming to regenerate constitutional order is to establish legitimacy. As already indicated legitimacy refers to the acceptance of the foundational principles of a state and to the constitution of a state. A people who see its state and government as having legitimacy have a sense of constitutional unity. Without this sense of unity, a state is in danger of serious conflict, and even collapse. A government can establish this sense of legitimacy over time by meeting the needs of the people, and by building a sense of purpose and unity amongst them. The ability to build legitimacy depends partly on the quality of dialogue between the people and the state. The making of a constitution, and later reforming it, is part of 
this exercise of consolidating the legitimacy of a state. The legitimacy of a state provides the foundation for the operation of democracy.

Democracy is an ancient concept that continues to evolve over time. In a broad sense it refers to the election of leaders by the people. People who elect their own leaders are said to be 'free', although this 'freedom' refers to their agreement to act as they wish within the bounds of the rights and responsibilities that are determined by the society's legal system and public culture. The idea of democracy is not to achieve 'total freedom' - for such a thing is impossible — but to provide a social and political society in which individuals are able to pursue goals of their own choosing, to fully develop their personalities, abilities and talents, and to contribute the fruits of their efforts back to their society. There is not one approach to democratic structure and procedure, but many. The majority of contemporary democratic states opt for forms of 'representative' democracy, in preference to 'direct' democracy. In political terms, much of this 'representation' occurs through party systems. But in the process of constitution-making we must remain aware that the current approach to so-called 'democratic institutions' is but one among many. It could be argued that the more party systems are developed, the less represented the people become, as it is the parties, rather than the people, who come to determine policy. Such reservations maybe raise the need for a reconsideration of the form of democratic system selected. However, democracy offers both legitimacy and accountability, since the people have control over their leaders and over the laws that bind them. Where these conditions are met a government acquires authority, and, possessing authority, becomes effective in governing with a sense of justice.

The quest for legitimacy and democracy is, then, linked to the quest for justice. People have an innate sense of injustice, in the sense that they know when they have been wronged, or harmed. The ability to govern justly, however, is not innate in the same way, but only comes with experience, wide knowledge of current conditions and past circumstances, a sense of compassion and an ability to remain impartial. In many systems of governance the 'justice system' refers to the court system alone, but socalled 'access to justice' is a matter that extends beyond the courts. The laws of a country must be just, the administration of government must be just and disputes must be solved in a just manner. A just society exercises both reward and punishment and a just society ensures the fair distribution of both welfare and wealth.

A final challenge of contemporary governance is the generation of social and economic prosperity. This challenge requires more than 'economic development', more than industrialisation and increased consumption and more than the spread of material benefits. It refers to the attainment of the well-being of the people, through their acquisition of material development in accordance with their own plans, activities and priorities. It refers, that is, to the development of the people's personalities in accordance with their own volition and choice. Questions of prosperity become linked to issues like taxation and the provision of welfare services.

These four challenges, attaining legitimacy, democracy, justice and prosperity, confront all systems of government, no matter which hemisphere, and no matter 
which culture. They relate to the quest for human rights, transparency, accountability and non-discrimination. When they are lost sight of, the idea of governance is reduced to the struggle for so-called power and struggles over the acquisition and distribution of limited resources.

Meeting the challenges of contemporary governance requires an evaluation of the constitution which cannot be rushed, which must be impartial, which must involve wide participation of the people, and which must meet their needs in the context of an emerging regional and global order. Such an evaluation may well revisit and revitalise traditional values of consultation, reciprocity and social solidarity, and more critically examine introduced structures of governance which produce conflict rather than progress. This can be done, but not without imagination and universal participation.

\section{ENDNOTES}

1 Lane, J-E. 1996. Constitutions and Political Theory. Manchester \& New York: Manchester University Press, pl0.

2 Governance for Sustainable Human Development, a UNDP Policy Document.

3 Commission on Global Governance, 1995. Issues in Global Governance: papers written for the Commission on Global Governance: London \& Boston: Kluwer Law International in association with the Commission on Global Governance. Agencies working at international level include ombudsmen, the Inter-Parliamentary Union, Electoral Authorities and Monitors, Transparency International, Human Rights Monitors, Media Monitors, International Institute for Democracy and Electoral Assistance, the United Nations and its many agencies.

4 Macdonald, B. 1996. Governance and political process in Kiribati. Canberra: National Centre for Development Studies; Paeniu, B. 1995. South Pacific: Traditional Governance and sustainable development in the Pacific. Economic Division Working Papers (No. 6), Canberra: ANU Research School of Pacific and Asian Studies; Taafaki, T. , \& Oh, J. 1995. Governance in the Pacific: Politics and Policy Success in Tuvalu. Canberra: National Centre for Development Studies Australian National University.

5 Giddens, A. 1991. Modernity and Self-Identity: Self and Society in the Late Modern Age. Chicago: Stanford University Press, pl4-15.

6 An example of the presuppositions of modernity in relation to electoral systems are articulated in Apter, D.E. 1961. Some Reflections on the Role of a Political Opposition in New Nations. Comparative Studies in Society and History 4: 154-168.

7 Dictionaries give the term "rule of law" a variety of meanings: "The Rule of Law, sometimes called "the supremacy of law", provides that decisions should be made by the application of known principles or laws without the intervention of discretion in their application" (Black's Law Dictionary. 1991, Minn: West Publishing);

"The principle that all citizens of this country are subject to the same laws, and that no one can be punished for something not expressed to be legal" (McFarlane, G. 1984. The Layman's Dictionary of English Law. Oxford: Pergaman Press. At p 252); 
"The general condition of a state in which laws are accepted and observed." (Curzon, L.B. 1983. A Dictionary of Law. At p 211).

8 Yeatman has highlighted the position of anthropology in the front lines of colonial ordering, "situated as it is as the knowledge discipline which has informed and legitimised the modern western project of civilization/colonisation on a world-system scale." Yeatman, A. 1994. Post-Modern Revisionings of the Political. Routledge: New York \& London, at p 32.

9 Regan, A. 1992. Constitutionalism, Legitimacy and the Judiciary. In James, R.W. \& Fraser, I. (eds), Legal Issues in a Developing Society. Faculty of Law, University of Papua New Guinea, at p 15.

10 Ghai, Y. 1990. Constitutional Reviews in Papua New Guinea and Solomon Islands. The Contemporary Pacific 2:2, 313.

11 Ghai, Y. Above n 10 at p 315.

12 Gawi, J. The Status of the Common Law under the Constitution, 13-14.

13 Solomon Islands Parliament. Hansard. 3rd Session, 19th Meeting, 21 March-12 April 1988, p305.

14 Five other parties remained in the coalition: the National Alliance, the Peoples' Progress Party, the Peoples' Action Party, the Melanesian Alliance and the Pangu Pati.

15 The parties involved are the Melanesian Alliance (MA), the National Alliance (NA), the Peoples' Action Party (PAP), the Movement for Greater Autonomy (MGA) and a number of Independents.

16 "No Party Registered", Post Courier (22 October 1999).

17 "Reforming the Political System of the Cook Islands". The report suggested reducing the term of Parliament from 5 years to 4; abolishing the Overseas Constituency, and reducing the number of Members of Parliament from 25 to 17. It also made recommendations concerning the qualifications of voters and candidates, switching to a preferential electoral system, reducing the campaign period and tightening the accountability of political party finances, including a system of recall, limiting the length of consecutive term of MPs to 16 years (including up to 12 years as a Minister and/or 8 years as Prime Minister), and introducing a leadership code.

18 The Vanua'aku Pati won 18, the Union of Moderate Parties 12, the National United Party 11, the Melanesian Progressive Party 6, the John Frum Movement 2, independent candidates 2, and the Vanuatu Republikan Pati 1 seat. A coalition government was formed by Donald Kalpokas (President of the Vanua'aku Pati), together with members of the Vanua'aku Pati (VP) and the National United Party (NUP).

19 The events of 2001 during which the Speaker of the Parliament, Paul Ren Tari, closed a session of Parliament in order to prevent debate on a no-confidence motion against the then Prime Minister Barak Sope provide another example of the courts becoming involved in parliamentary business. The members of the oppostition filed a petition in the Supreme Court to require the Speaker to convene Parliament and allow the motion to be debated. The judgments relating to this issue can be found at http://www.vanuatu.usp.ac.fj/journal_splaw/Special_Interest/Vanuatu_2001/Main.html (Accessed 30/10/01). 
20 Constitutional Amendments 18 (concerning the Commencement of Constitutional Amendments Nos. 16 and 17) and 19 reduced the period for nomination of candidates from 35 to 28 days, reduced the formal campaign period, created provision for postal votes by citizens resident abroad, and for the holding of direct elections for local-level government council presidents. The amendments replaced the Organic Law on National Elections, the Organic Law on Elections (Amendment No 1), Electoral Regulation 1977, Electoral (Amendment) Regulation 1987 the Local Government (Electoral Provisions) Regulation and other related legislation.

21 Organic Law on the Integrity of Political Parties and Candidates. Parts I, II, II, IV \& VIII came into effect on 22/2/01. The rest of the Act came into effect on 22/2/02.

22 Other sections of the law require a political party to have more than ten Members of Parliament in order to be registered and receive State funding; to deny registration to a party that is regionally rather than nationally based, which does not portray nationalism, or which "portrays sinister tactics designed to work against the National Constitution"; to require all registered political parties to have a registered office, a Constitution, a secretariat and a National policy; and require transparency of the sources of party funds “Defector MPs Face Instant Dismissal”, Post Courier (20 October 1999).

23 "Pangu Offers New Ways", Post Courier (20 October 1999).

24 “Architect Urges Radical Change", Post Courier (20 October 1999).

25 Throughout the Pacific, but particularly in Melanesia, 'big man' is used to refer to an important public figure. Theconcept combines elements of contemporary politics with traditional notions of the obligations of people holding high status.

26 For further examples, Hill, T. The Vanuatu Ombudsman, in this volume, details instances of public agitation because of corruption within the executive within the Vanuatu context.

27 The military activities of the Isantabu Freedom Fighters (IFF) resulted in the departure of at least 10,000 Malaitans - although they also disrupted the economic and political stability of the entire country.

28 For more information on the background to the situation in Solomon Islands and current updates see ttp://rspas.anu.edu.au/melanesia/index.htm (Accessed 31/10/01); http://www.peoplefirst.net.sb/Default.htm (Accessed 31/10/01).

29 Clause 1.

30 For more information on the background to the situation in Bougainville and current updates see http://rspas.anu.edu.au/melanesia/bougainvillepeacedocs.htm (Accessed 31/10/01); http://www.unpo.org/member/bougain/bougain.html (Accessed $30 / 10 / 01)$.

31 Ghai, Y. A Coup by Another Name? The Politics of Legality. The Contemporary Pacific $2: 1,11-35$.

32 The key issues dividing the major political parties were the "paramountcy" of Fijian chiefs, the electoral system (a communal system, which did not allow cross voting), the existence of and powers of the senate (many of whose number were appointed by the Great Council of Chiefs). The Constitutional Review Commission received more than 700 submissions 
from the major political parties and the public at large. The submission of the ruling Soqosoqo ni Vakavulewa ni Taukei (SVT) stated emphatically that the 1990 constitution, which weights the allocation of political power in favour of ethnic Fijians, must continue to form the basis of Fiji's constitutional order. The submissions of the chief of Rotuma's Royal Malmahan Clan indicated that Rotumans did not want to be mentioned in the Constitution, and preferred some form of free association.

34 Habermas, J. (trans. Rehg, W.) 1995. Between Facts and Norms. MA: MIT Press. At p 449.

35 Habermas, J. 1995. Moral Consciousness and Communicative Action. In Lenhardt, T. and Weber Nicholsen, S. (trans) Moral Consciousness and Communicative Action. Cambridge MA: MIT Press. p 116.

36 Habermas, J. (trans. McCarthy, T.) 1981. The Theory of Communicative Action Boston: Beacon Press.

37 "Mollok Wants a Total Review", Post Courier (20 October 1999); "Political Change Vital (Mollok", Post Courier (22 October 1999).

38 "Western Ways 'Source of Strife", Post Courier (22 October 1999).

$39 \mathrm{Mr}$ Mollok said the importance of the proposed Organic Law should not be rushed "The convention has revealed that the proposed law is being rushed and that it may end up being unworkable in many aspects as is the case with the Organic Law on Provincial and Local Level Governments." He said that "while there was wide support for the proposed law to be enacted, there were suggestions that the Government might not have a consolidated number on the matter. This was illustrated by the differing views expressed by leaders of the current coalition party. The CDC had been told to come up with this historic piece of legislation but it seemed the Government was not really showing its genuineness by rushing the Bill, instead of allowing for adequate public awareness and adequate funding for the commission to carry out this task": "CDC Chief Calls on Govt to Take Lead", Post Courier (22 October 1999). See also, "Law to Control Politicians a Must (CDC Chairman)", Post Courier (25 October 1999).

40 "Mollok Calls for More Time, Funds", Post Courier (25 October 1999).

41 “Sacked Chairman Cries Foul”, Post Courier (16 November 1999).

42 Lal, B.V. 1998. Another Way: the Politics of Constitutional Reform in Post-Coup Fiji. Canberra: National Centre for Development Studies. 